\title{
Fournier Syndrome-Surgical and Intensive Care Treatment
}

\author{
Paoliello V,* Carlo Paoliello G \\ Rua Alberto De Oliveira Santos, Brazil
}

\begin{abstract}
Fournier's Gangrene, also referred to as necrotising fasciitis, Mellene Syndrome or Fournier Syndrome (FS), is a soft-tissue acute infection of the perinium with secondary necrotising cellulitis caused by anaerobic germs or gram-negative bacilli or both. This infection may develop in apparently normal skin, affects the tegumentary and fascial planes but it affects the muscle - aponeurotic plane very rarely dissecting the necrotic tissues, as it rapidly moves towards sepsis, with multiple failure of the organs and death. Treatment consists of agressive surgical debridement, broad spectrum antibiotic therapy, hyperbaric oxiygen therapy (OHB) and other complementary actions.
\end{abstract}

Keywords: Fournier disease,Necrotising fasciitis, Sepsis, Intense care treatment

\section{Introduction}

In this paper we deal with the rapidly evolving polymicrobial infection. This is a rare infection whose diagnosis, if rapid and precise, will reveal the evolution of the clinical conditions. Normally, the association of penicillin, amoxicillin, metronidazole, clindamycin and cephalosporin, whether oral or endovenous, by themseles or conjugated, will be used, depending on the severity of the illness. In case the disease affects the internal organs such as the intestine or the kidneys, it may be necessary to submit the patient to colostomy and ureterostomy or nephrostomy. In the event of impairment of the scrotal sac and testicles, removal can be needed (emasculation, orchidectomy) but is very rare, because the mesotelialmembrane(vaginal) prevents to spreading to the testicule. Whatever the hypothesis, surgical treatment imposes itself. Anaerobic and aerobic microorganisms acting in an isolated or synergetic way promote obliterating endarteritis, leading to thrombosis of the cutaneous and subcutaneous vessels of the anal, perianal and genital regions, necrotising the tissues of the regions affected.

This gangrene was named Fournier's Gangrene, in honour of the French dermatologist, Jean Alfred Fournier, for his contribution to the study of this disease. Fournier described it in detail in his work in the years 1863 and 1864. Similar report previous to
Fournier was attributed to Baurienne (1761). In most cases, the starting point is in the anorectal procedures, simple as they may be, such as a biopsy. The anorectal region has fascial spaces and planes that may result in a fast spreading infection. This infection is frequently associated with debilitated patients. It is considered a fulminant disease, as can be inferred from a death rate around $40 \%$ and $67 \%{ }^{1-4}$ The interval between the beginning of the infection and treatment will determine the prognosis. Patients treated within four days of the evolution of the disease have presented a better prognosis than those who did not received any therapy within seven or more days of the onset of the disease. In general, the latter had lectal exit.

\section{Epidemiology}

Fournier's Gangrene prevails among male patients at a rate of ten to one. However, it does not restrict itself to young individuals, and may affect all age ranges, with average age being around 50 years. ${ }^{1,5,6}$ It is not a common disease: reports in the relevant literature account for no more than 300 cases. $^{7}$ Correlation of Fournier's Gangrene with diabetes mellitus is around 40 to $60 \%$ of the cases, with alcoholism 25\%, and hypertension, tabacco addition, immunosuppression (e.g: bearers of HIV), obesity, patients receiv-

\begin{tabular}{|c|l|}
\hline Quick Response Code: & *Corresponding author: Victor Paoliello, RuaCaramuru 104, Vitória ES 29015020, Brazil \\
Received: 15 May, 2021 & Published: 15 June, 2021 \\
\hline & Citation: Paoliello V, Carlo PG. Fournier Syndrome-Surgical and Intensive Care Treatment. Mod \\
Res Plast Recon Sur. 2021;1(2):1-4. DOI: 10.53902/MRPRS.2021.01.000507
\end{tabular}


ing chemotherapy, leukemia bearers, among others, $50 \% \cdot{ }^{4,5,8,9}$ Considering the increasing number of HIV cases, some authors suggest that Fournier's Gangrene might become the first manifestation of this disease.

\section{Etiology}

It is expected that a careful investigation might show the entrance door. Generally Fournier's Gangrene is related to either the urogenital and digestive tracts, or cutaneous manifestations. ${ }^{6,7,10} \mathrm{~A}$ significant number of occurrences of this disease has indeterminate cause $^{4,5,6,10,11}$ and some review articles refer to cutaneous affections as the main site of inffection focuses (24\%). Bartholinitis, superficial subcutaneous abcess as well as complications of common surgical procedures such as vasectomy, hemorrhoidectomy, orchidectomy(rare), herniorrhaphy, hydrocelectomy and postectomy stand out among them. ${ }^{1,12}$

\section{Microbiology}

This is a polymicrobial infection where aerobic and anaerobic bacteria are detected. These bacteria are not pathogenic by themselves but, once they are associated with other factors, given ideal conditions, they can lead to devastating infections. ${ }^{1-3,5,6,8,10,13} \mathrm{Cul}-$ tures done on patients gave evidence of the presence of up to four strains of microorganisms:

Gram-negative aerobes: Escherichia coli, klebsiella pneumoniae, pseudomonas aeruginosa, and proteus mirabilis. ${ }^{1,2,3,5,8}$

Gram-positive: Staphylococcus aureus, Staphylococcus epidermidis, Viridans Streptococcus and Streptococcus fecalis, anaerobes (bacteroides fragilis, melaninogenicus bacteroides and sp clostridium) - not perfringens. ${ }^{1-3,5,6,8}$ Acting in synergy, these bacteria operate through different mechanisms, contributing to the severity and dissemination of the process. Vascular occlusion occurs when there is aggregation of plaques, and this results from the heparinase produced byanaerobes and the action of gram-negative bacteria, inducing thrombosis. Tissue destruction is due to the direct action of the hialuronidase produced by the action of Streptococcus, Staphylococcus and bacteroides on the connective tissue. The action performed by estreptokinases and streptodornases makes tissue destruction yet more aggravating. Fagocitose is inhibited and bacteroides stop aerobes destruction. ${ }^{14-24}$

\section{Clinical Condition}

Pain, erythema, edema and necrosis of the testicular sac, in the perineal or perianal regions, associated with fever and chill, are some of the clinical manifestations of Fournier's gangrene. ${ }^{24-30}$ The disease may manifest itself insidiously or through rapid sepsis signs and symptoms. Local manifestations include flictenes, crepitation, cyanosis and secretion of stinking smell.Cutaneous manifestations and spread along deep planes run parallel.Localised cellulitis that does not respond to specific treatment leads one to assume that it is a case of Fournier`s gangrene syndrome.If such signs and symptoms are found to be present in diabetic, alcoholic, immunosupressed, traumatized patients, debridement or surgical procedures, as well as in patients with an infected urinary tract, diagnosis is arrived at. ${ }^{31-32}$ In the old days, Fournier's Gangrene was taken for a rare disease, yet the abusive use of antibiotics increased its incidence. At this moment, pain has been somewhat eased, due to impairment of the nerves, which further complicates the clinical condition. ${ }^{33-35}$ Symptoms associating fever with a toxinfection condition plus nausea and vomiting, tachypnoea and mental alterations show that the disease is about to be intalled. The clinical condition presents itself suddenly with edema, sudden painful scrotal erithema, scrotal pain in patients with no complaints, darkening of the cutaneous tissue progressing towards gangrene, strong smell and local subcutaneous enphysema. ${ }^{35-40}$ The reason for its prevalence in the scrotal region is not yet known.It is assumed that dissemination is facilitated by poor hygiene and less air circulation, skinfolds hosting bacteria that penetrate the skin, following trauma, and significant looseness of the subcutaneous cell tissue (SCCT). Although diagnosis could be made through clinical evidence, doubtful cases should be evaluated by means of imaging, radiology, ultrasonography and tomography, since they might serve as tools to define the cause and extension of the lesion. ${ }^{40-42}$

\section{Treatment}

It is based on the use of broad-spectrum antibiotics including anaerobic, aerobic, gram-positive and gram-negative bacteria. The surgical procedure includes broad debridement, indispensable for the full removal of devitalised tissues, in order to interrupt the infectious process and reduce systemic effects. This surgical removal may have to go through a sequence of stages until it reaches its final objective, that of keeping sound tissue only. In the case of fecal contamination, it is suggested that the derivation procedure be adopted, like in colostomy. In urine contamination, vesical catheterism is required. Apart from specific therapeutics, one should consider the possibility of using clostridium tetani and fungal infection, once the necessary measures are taken.

\section{Antibiotic Therapy}

Infection acquired in the community: use ampicillin and sulbactam 1.5 to $12 \mathrm{~g}$ divided into four doses, or piperacillin-tazobactam 13.5 to $18.0 \mathrm{~g} /$ day in four doses, associated with ciprofloxacin $400 \mathrm{mg}$ IV $12 / 12 \mathrm{~h}$ or aminoglycosides (gentamicin 3.0 to $5.0 \mathrm{mg}$ / $\mathrm{kg} /$ day or amikacin $-15 \mathrm{mg} / \mathrm{kg} /$ day i x day, not to exceed $1.5 \mathrm{~g}$ day). Another scheme is the association of third generation cephalosporinswith anaerobicides (metronidazole $1.5 \mathrm{mg}$ to 2.0 in three doses, or clindamicin $900 \mathrm{mg}$ to $2400 \mathrm{mg}$ in four doses).

Infection related to invasive procedures in the hospital environment: carbapenems (imipenem- $2 \mathrm{~g}$ to $4 \mathrm{~g}$ /day IV in four doses or meropenem 3 to $6 \mathrm{~g} / \mathrm{day}$, IV in three doses, associated with vancomycin $2 \mathrm{~g} /$ day in two doses.

Based on microbiological results, antimicrobial therapy can be adjusted and its duration will depend on the patient's clinical evolution (usually three to four weeks).

Collagenase lyophilised can be used as local treatment (it digests the necrotic tissue); activated charcoal, sugar, honey, papain, hydroxide of magnesium and others. Mechanic cleaning with physiological solution and neutral soap should also be considered. 


\section{Hyperbaric Oxigen Therapy (OHB)}

The purpose of this therapy is to increase or maintain oxygen saturation above $90 \%$, thus correcting the destruction caused by hypoxemia (it increases the oxygen level exchanged between blood and tissues).

Parameters to be observed for OHB:

PAO2 (oxygen arterial pressure) between 90 and 100mmhg (it is inefficient below this level).

$\mathrm{SatO}_{2}>=97 \%$ (monitored by pulse or arterial blood oximetry).

$\mathrm{SvO}_{2}$ (venous oxygen saturation)

$\mathrm{PvO}_{2}$ (mixed venous oxygen pressure).

Ca $\mathrm{O}_{2}$ (arterial oxygen content).

$\mathrm{PO}_{2}\left(\mathrm{O}_{2}\right.$ systemic liberation $)$.

OHB should cover, on the average, from 10 to 15 sessions, depending on the evolution of the clinical condition. It has adverse effects that, depending on the dose and the time of exposition to oxygen, it may be damaging to the organism, affecting particularly the lungs and the central nervous system. Among possible manifestations, are contractions, convulsions, dry cough, traqueobronquitis, thoracic pains, etc.

\section{Prognostic Factors}

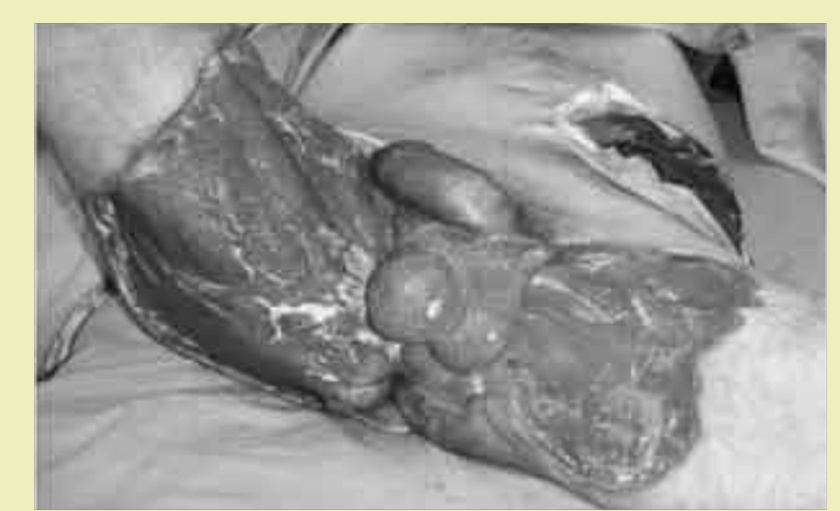

Figure 1: Scrotum Necrosis, perineal and perianal regions.

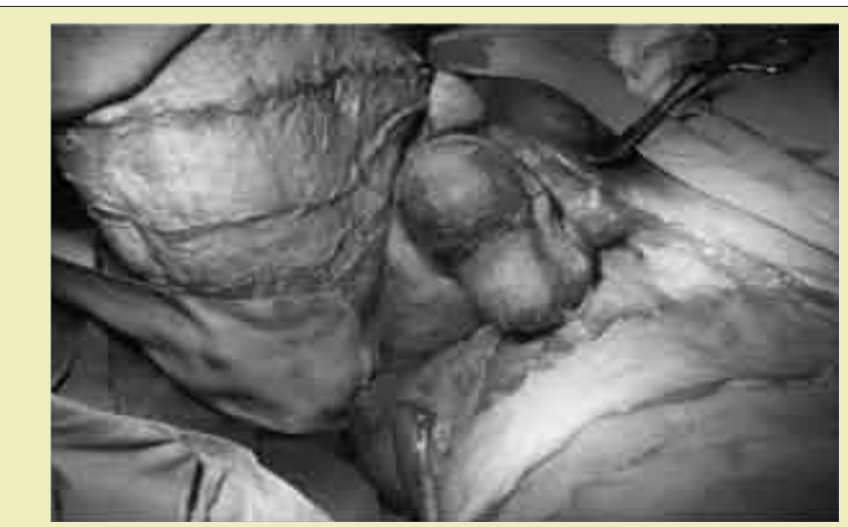

Figure 2: Surgical Debridement.
Although no consensus has been reached so far among authors, the main factors related to mortality from Fournier's Gangrene appear to be the time elapsed from the initiation of the disease to surgical treatment, the early use of hyperbaric oxigen therapy, the extension of the necrosis and systemic repercussions(Figures 1-4).

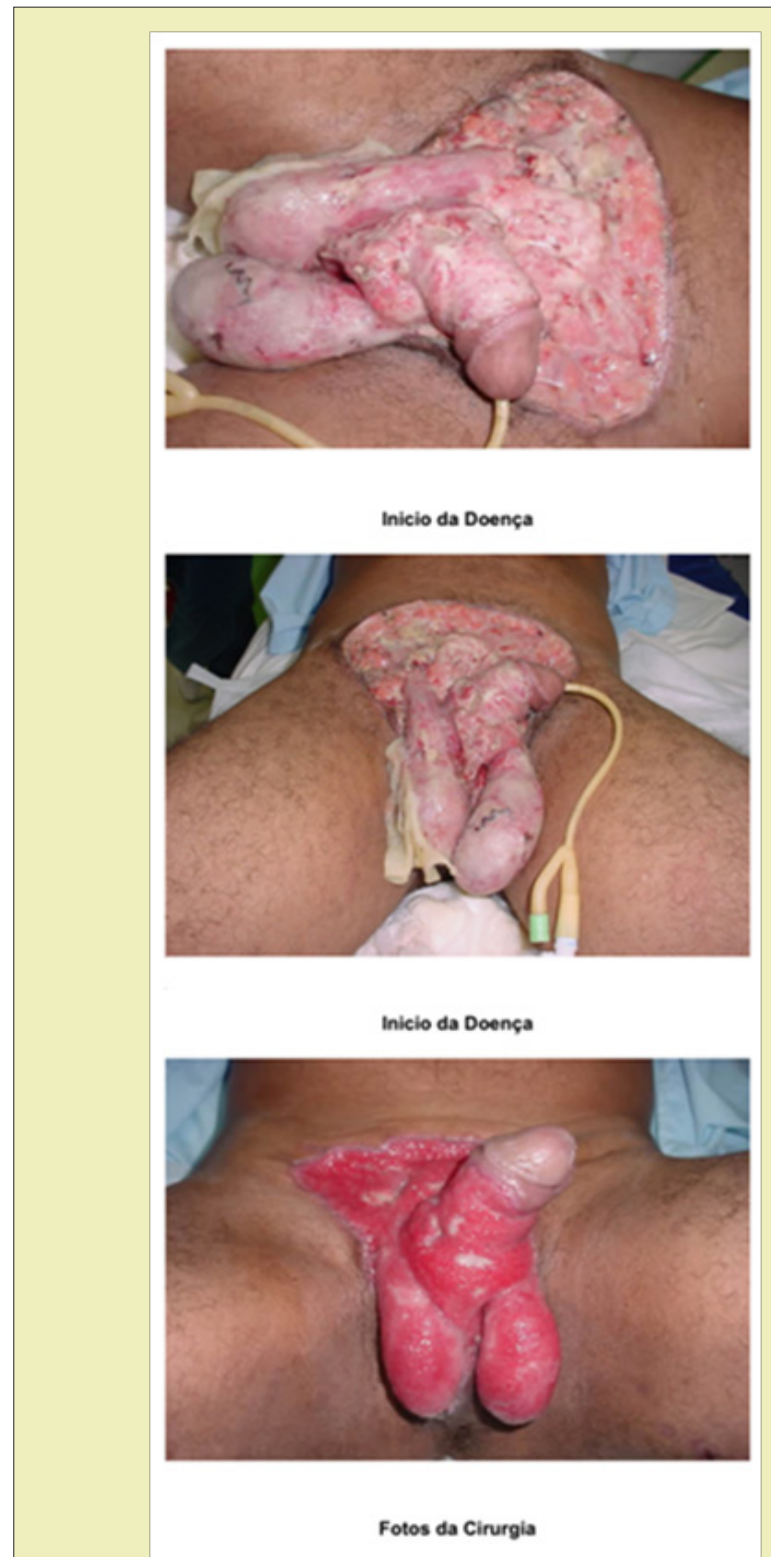

Figure 3: Post-surgery $24^{\text {th }}$ day, granulation tissue.

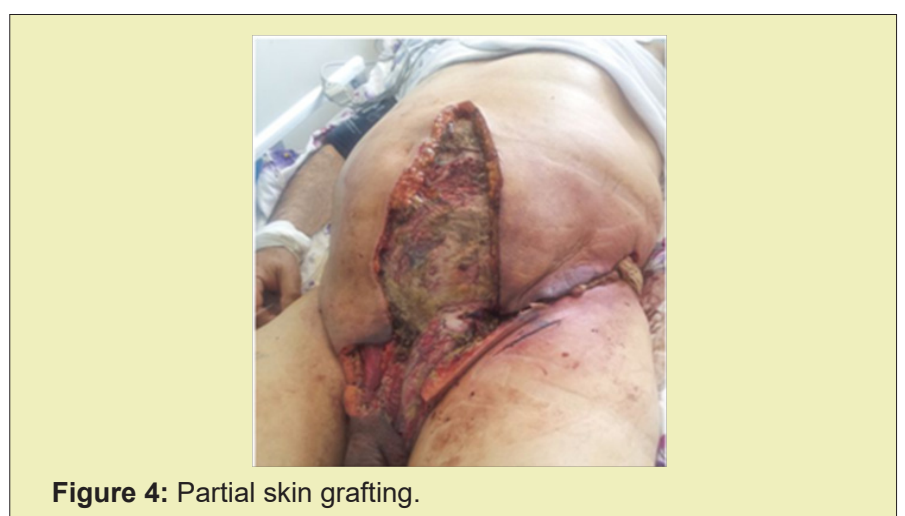




\section{Acknowledgments}

None.

\section{Funding}

None.

\section{Conflicts of Interest}

Author declares that there is no conflict of interest.

\section{References}

1. Yaghan RJ, Al-Jaberi TM, Bani-Hani I. Fournier's gangrene. Changing face of the disease. Dis Colon Rectum. 2000;43(9):1300-1308.

2. Jeong HJ, Park SC, Seo IY, Rim JS. Prognostic factors in Fournier's Gangrene. Int J Urol. 2005;12(12):1041-1044.

3. Norton KS, Johnson LW, Perry T, et al. Management of Fournier's gangrene: an eleven year retrospective analysis of early recognition, diagnosis and treatment. Am Surg. 2002;68(8):709-713.

4. Safioleas M, Stamatakos M, Mouxopolus G, et al. Fournier's gangrene: exists and it is still lethal. Int Urol Nephrology. 2006;38:653-657.

5. Eike N. Fournier's gangrene: a review of 1726 cases. Br J Surg. 2000;87(6):718-728.

6. Spirnak JP, Resnick MI, Hampel N, et al. Fournier's gangrene: report of 20 patients. J Urol. 1984;131:289-291.

7. Upport RN, Levy HM, Patel PH. Case 54; Fournier's Gangrene. Radiology. 2003;223:115-7.

8. Smith GL, Bunker CB, Dinneen MD. Fournier's gangrene. Br J Urol. 1998;81(3):347-355.

9. Clayton MD, Fowler JE, Sharifi R. Causes, presentation and survival of 57 patients with necrotizing fasciitis of the male genitalia. Surg Gynaecol Obstetric. 1990;170(1):49-55.

10. Morpurgo E, Galandiuk S. Fournier's gangrene. Surg Clin Nort Am. 2002;82(6):1213-1224.

11. Tran HA, Hart AM. Fournier's gangrene. Intern Med J. 2005;36(3):200201.

12. Féres 0 , Andrade JI, Rocha JJR, et al. Fournier's gangrene: a new anatomic classification. In: Reis Neto JA, editors. Proceedings of the 18th Biennial Congress of the International Society of University Colon and Rectal Surgeons 2000 July 23-26; São Paulo, Brazil. Bologna: Monduzzi Editore; 2000: 103-7.

13. Murakami M, Okamura K, Hayashi M, et al. Fournier's gangrene treated by simultaneously using colostomy and open drainage. J Infect. 2006;53(1):15-18

14. Laucks SS. Fournier's gangrene. Surg Clin North Am. 1994;74(6):13391352.

15. Stephens BJ, Lathrop JC, Rice WT, et al. Fournier's Gangrene: historic (1764-1978) versus contemporary (1979-1988) differences in etiology and clinical importance. Am Surg. 1993;59(3):149-154.

16. Fournier JA. Gangrene foudroyante de la verge. Med. Prát. 1883; 4; 58997. Fournier JÁ Étude clinique de La gangrene foudroyante de La verge. Sem Med. 1884;4:69.

17. Yanar H, Taviloglu K, Ertekin C, et al. Fournier's gangrene: Risk factors and strategies for management. World J Surg. 2006;30(9):1750-1754.

18. Rotunda N. Fournier's gangrene: An unusual presentation of sepsis. $J$ Emerg Med. 2002;23(4):413-414.

19. Leonhard M, Steinstraesser L, Druecke D, et al. Fournier's gangrene after milliganmorgan hemorrhoidectomy requiring subsequent abdominoperineal resection of the rectum: report of a case. Dis Colon Rectum. 2004;47(10):1729-1733.

20. Korkut M, Icoz G, Dayangac M,et al. Outcome analysis in patients with Fournier's gangrene. Report of 45 cases. Dis Colon Rectum. 2003;46(5):649-652

21. Atakan IH, Kaplan M, Kaya Esat, et al. A lifethreating infection: Fournier's gangrene. Int Urol Nephrology. 2002;34(3):387-392.

22. Nomikos IN. Necrotizing perineal infections (Fournier's disease): old remedies for an old disease. Int J Colorectal Dis. 1998;13(1):48-51.

23. Tuncel A, Aydin O, Tekdogan U, et al. Fournier's gangrene: three years of experience with 20 patients and validity of the Fournier's gangrene Severity Index Score. Eur Urol. 2006;50(4):838-843.

24. Ochiai T, Ohta $\mathrm{K}$, Takahashi $\mathrm{M}$, et al. Fournier's gangrene: report of six cases. Surg Today. 2002;31(6):553-556.

25. McKay TC, Waters WB. Fournier's gangrene as the presenting sign of an undiagnosed human immunodeficiency virus infection. $J$ Urol. 1994;152(5):1552-1554.

26. Quatan N, Kirby RS. Improving outcomes in Fournier's gangrene. BJU Int. 2004;93(6):691-692.

27. Moreira C, Wongpakdee S, Gennaro A. A foreign body (chicken bone) in the rectum causing perirectal and scrotal abscess. Dis Colon Rectum. 1975;18(5):407-409.

28. Laor E, Palmer LS, Tolia BM, et al. Outcome prediction in patients with Fournier's gangrene. J Urol. 1995;154(1):89-92.

29. Mindrup SR, Kealey GP, Fallon B. Hyperbaric oxygen for the treatment of Fournier's gangrene. J Urol. 2005;173(6):1975-1977.

30. Korhonen K, Hirn M, Niinikoski J. Hyperbaric oxygen in the treatment of Fournier's gangrene. Eur J Surg. 1998;164(4):251-255.

31. Dias MD. Oxigenoterapia hiperbárica em pacientes portadores de lesões teciduais. revisão de 1506 casos. [Tese de Doutorado], São Paulo: Faculdade de Medicina - USP. 2004.

32. Yeniol CO, Suelozgen T, Arslan M, et al. Fournier's gangrene: experience with 25 patients and use of Fournier's Gangrene Severity Index Score. Urology. 2004;64(2):218-222.

33.h t t p : / / b o a s a d e. u o l. c o m . b r / li b / S how D o c. $\mathrm{cfm} ?$ LibDocID=2589\&ReturnCatID $=1746$

\section{Síndrome deFournier.}

35. Rthur Leopoldo Hoffmann, Luiz Fernando Iglesias, Walter Wendhausen Rothbarth. Fournier's Syndrome: Case Report. Arquivos Catarinenses de Medicina. 2009;38(1):104-105.

36. Candelaria Pap; Klug WA; Capelhuchnik P; Fang CB. Síndrome de Fournier: Análise dos Fatores de Mortalidade. Rev bras Coloproct, 2009;29(2):197-202.

37. Cavalini F, Moriya TM, Pelá NTR. Síndrome de Fournier: a percepção do seu portador. Rev Esc Enferm USP. 2002;36(2):108-114.

38. Whonamedit. Jean Alfred Fournier.

39. Laucks II SS. Gangrena de Fournier. Cirúrgicas da América do Norte. 1994; 6:1405-1418.

40. Declair V. Efeitos das triglicérides de cadeia média na aceleração do processo de cicatrização de feridas. Nutrição Enteral e Esportiva. p. 4-8.

41. Luz MM P, Carneiro LR. Doenças Anorretais Incomuns. In: Geraldo Magela Gomes da Cruz. Coloproctologia Terapêutica. $1^{\text {st }}$ edn. Rio de Janeiro: Revinter. 2000;3:2276-2285.

42. Gangrena de Fournier. 